\title{
TUBERKULÓZIS NYOMAI KÉSŐ NEOLITIKUM - KORA RÉZKORI MAGYARORSZÁGI EMBERI MARADVÁNYOKBAN (ALSÓNYÉK-BÁTASZÉK, DÉL-MAGYARORSZÁG)
}

\author{
Pósa Annamária ${ }^{1,2}$, Mende Balázs Gusztáv ${ }^{1}$, Köhler Kitti ${ }^{1}$, Osztás Anett ${ }^{1}$, \\ Frank Maixner $^{3}$, Albert Zink ${ }^{3}$, Christophe Sola ${ }^{4}$, Olivier Dutour ${ }^{5,6}$, Molnár Erika $^{2}$ és \\ Pálfi György ${ }^{2}$
}

\begin{abstract}
${ }^{1}$ Magyar Tudományos Akadémia, Bölcsészettudományi Kutatóközpont, Régészeti Intézet, Archeogenetikai Laboratórium, Budapest; ${ }^{2}$ Szegedi Tudományegyetem, Természettudományi és Informatikai Kar, Embertani Tanszék, Szeged; ${ }^{3}$ Institute for Mummies and the Iceman, EURAC Research, Bolzano, Italy; ${ }^{4}$ Institut de Génétique et Microbiologie UMR 8621 Equipe IGEPE, Orsay, France; ${ }^{5}$ Laboratoire d'Anthropologie biologique Paul Broca, Ecole Pratique des Hautes Etudes, UMR 5199 PACEA, Universite de Bordeaux, Pessac, France; ${ }^{6}$ Department of Anthropology, University of Western Ontario, Canada
\end{abstract}

Pósa A., Mende B. G., Köhler K., Osztás A., Maixner, F., Zink, A., Sola, C., Dutour, O., Molnár E., Pálfi Gy.: Traces of tuberculosis in Late Neolithic - Early Copper Age human skeletal remains from Hungary (Alsónyék-Bátaszék, South-Hungary). Alsónyék-Bátaszék in Southern Hungary is one of the largest late Neolithic settlements and cemeteries excavated in Central Europe. In total, 2,359 burials from the Late Neolithic - Early Copper Age Lengyel culture were found between 2006 and 2009. Anthropological investigations previously carried out on individuals from this site revealed an interesting paleopathological case of tuberculosis in the form of Pott's disease dated to the early 5th millennium BC. In this study, selected specimens from this osteoarcheological series were subjected to paleomicrobiological analysis to establish the presence of MTBC bacteria. As all individuals showing clear osteological signs of TB infection belonged to a single grave group, 38 individuals from this grave group were analysed. The sample included the case of Pott's disease as well as individuals both with and without osseous TB manifestations. The presence of TB DNA in the individual with Pott's disease was established, confirming the occurrence of TB in Neolithic populations of Europe. Moreover, our molecular analysis indicated that several other individuals of the same grave group were also infected with $T B$, opening the possibility for further analyses of this unique Neolithic skeletal series.

Keywords: Skeletal tuberculosis; Late Neolithic human bone samples; aDNA; Mycobacterium tuberculosis complex; Carpathian Basin.

\section{Bevezetés}

Paleopatológiai és molekuláris biológiai ismereteink egyaránt arra utalnak, hogy a humán tuberkulózis a legrégebbi bakteriális fertőző betegségeink egyike (pl.: Ortner 2003, Gutierrez és mtsai 2005, Hershkovitz és mtsai 2008, Donoghue 2009, Baker és mtsai 2015, Donoghue és mtsai 2015, Pálfi és mtsai 2015). A megbetegedések száma ugyanakkor napjainkban is nagy méreteket ölt: a tbc pandémiás megjelenésü, a Földön több milliárd ember hordozza a Mycobacterium tuberculosis baktériumot, évente közel tízmillió új megbetegedést és több mint egymillió halálesetet okozva (WHO 2015). A humán tuberkulózis kialakulásáért leggyakrabban a Mycobacterium tuberculosis (Cole és 
mtsai 1998), ill. a M. bovis és M. africanum kórokozók a felelősek. A humán- és állatgyógyászati szempontból egyaránt jelentős, gümőkóros elváltozást kiváltani képes, egymással közeli rokon kórokozókat tömörítő Mycobacterium tuberculosis komplexbe sorolják még a M. microti, M. canetti, M. caprae, M. pinnipedii baktériumfajokat is (Smith és mtsai 2009).

A tuberkulózis népegészségügyi fontosságára tekintettel az utóbbi években kiterjedt kutatások folytak a tbc-t okozó kórokozók biológiai, genetikai és evolúciós tulajdonságainak tisztázására, pontosítására. A legáltalánosabban elfogadott elvek szerint a Mycobacterium tuberculosis komplex tagjai közös ősre tekintenek vissza - amelyet egyes szerzők Mycobacterium prototuberculosis-ként azonosítanak (Gutierrez és mtsai 2005). Az utóbbi évtizedben számos tanulmány foglalkozott a humán tuberkulózis és kórokozója/kórokozói molekuláris evolúciós kérdéseivel. Az egyes kutatói csoportok által megalkotott evolúciós modellek sok pontban eltérnek, különös tekintettel a $\mathrm{M}$. tuberculosis konkrét megjelenési idejét illetően, abban azonban a kutatók többsége egyetért, hogy nagyon régóta létezett olyan, az emberi evolúció valamely stádiumában már a gümőkór kialakulásában (is) szerepet játszó Mycobacterium vonal, amely együtt evolválódott az emberi gazdaszervezettel, ill. magával az emberiséggel (pl. Gutierrez és mtsai 2005, Wirth és mtsai 2008, Brisse és mtsai 2009, Comas és mtsai 2013, Bos és mtsai 2014, Boritsch és mtsai 2014).

A neolitikum során jelentős társadalmi és gazdasági változások zajlottak le, amelyek a települések kialakulásához, a növénytermesztés elterjedéséhez valamint az állatok háziasításához vezettek. Ez utóbbi folyamat - a domesztikáció - eredményezte azt, hogy az ember és korábban vadon élő állatfajok tartós fizikai közelségbe kerültek. A neolitizáció jelenségei együttesen új lehetőségeket teremtettek egyes fertőző megbetegedések - esetünkben a tbc - átadására/terjedésére (háziállat-háziállat, háziállatember, ember-ember relációkban egyaránt). Ezek alapján alakult ki, és tartotta magát hosszú ideig az elmélet, hogy a M. tuberculosis a M. bovis-ból alakult ki a domesztikáció során (ill. azt követően) a szarvasmarhákról történő átvitellel (pl.: Cockburn 1963, Ortner 2003). Számos tanulmány, elsősorban a szekvencia-alapú evolúció-genetikai vizsgálatok, ellentmondanak ennek a tézisnek, megerősítve azt, hogy a M. tuberculosis komplex törzsek reduktív evolúciós lépések során egy ősi M. tuberculosis-progenitor formából alakultak ki, és ezek vezettek a modern M. tuberculosis törzsek kialakulásához, később M. africanum és végül M. bovis megjelenéséhez (Brosch és mtsai 2002, Filliol és mtsai 2006, Hershberg és mtsai 2008). Az ősi humán csontmaradványokon fellelhető tbcspecifikus csontelváltozások modern genetikai vizsgálatai szintén hozzájárulnak ahhoz, hogy jobban megértsük ennek a pusztító betegségnek az előfordulását és terjedését egy olyan fontos időszakban, mint a neolitikum. Az MTB aDNS eredmények, a leletek makro-morfológiai adataival és a lipid biomarker alapú tbc diagnosztikával együtt biomolekuláris és oszteológiai bizonyítékát nyújtották nagyon régi emberi tbc fertőzéseknek a korai neolitikumból, így pl. az izraeli helyszínü, Atlit-Yam (Izrael) lelőhelyről származó két, 9250-8160 évesnek datált mintából. Európában az eddigi legrégebbi, morfológiai és molekuláris vizsgálatokkal is tanulmányozott tuberkulózis eseteket Magyarországról (Masson és mtsai 2013, 2015) és Németországból (Nicklisch és mtsai 2012), egyaránt neolit lelőhelyekről publikálták. A felsorolt tanulmányok jelentősége abban rejlik, hogy különböző ásatások számos csontmintája segítségével betekintést nyújtanak magyarországi és közép-németországi késő neolit populációk egészségi állapotába. 
Tanulmányunkban további paleopatológiai és molekuláris bizonyítékokkal támasztjuk alá a humán tbc európai neolit kori jelenlétét. Egy Pott-gibbus jellegzetes tüneteit mutató csontvázmaradvány esetében molekuláris vizsgálatunk az egyén fertőzöttségét támasztja alá - a csontléziók azonban nem csak fertőzöttségről, hanem megbetegedésről, és annak súlyos, krónikus változatáról is árulkodnak (Köhler 2012, Köhler és mtsai 2012). Paleomikrobiológiai vizsgálataink más egyének esetében is jelezték a tbc-fertőzést az Alsónyék-Bátaszék lelőhely ugyanezen sírcsoportjából, további kutatási perspektívákat nyitva ebben az egyedi, neolit kori oszteoarcheológiai szériában.

\section{Anyag és módszer}

\section{Az oszteológiai széria}

Alsónyék-Bátaszék lelöhely a Dél-Dunántúlon, a Duna közelében helyezkedik el. A prehisztorikus település és temető feltárására 2006 és 2009 közötti időszakban került sor. Összesen 2359, késő neolit-kora rézkori Lengyel kultúrából (Kr.e. 5. évezred első fele) származó sírhelyet tártak fel (Köhler 2012, Köhler és mtsai 2012, 2013, Zalai-Gaál és mtsai 2008). Mai ismereteink szerint ez az egyik legrégebbi és legnagyobb feltárt neolitkori település Közép-Európában. Az Alsónyék-Bátaszék lelöhelykomplexum (1. ábra) része az az Alsónyék-Kanizsa dülő (vagy 010/B), ahol a feltárt 862 sír egyikéből került elő az első tbc-re utaló paleopatológiai eset (Zalai-Gaál és mtsai 2009). A sírok kisebb-nagyobb csoportokba rendezettek, ezért kronológiai és/vagy családi temetkezés feltételezhető. A sírokban a holttestek zsugorított temetkezésnek megfelelően a jobb oldalukra fektetve helyezkedtek el, ami szokványosnak mondható ebben az időszakban.

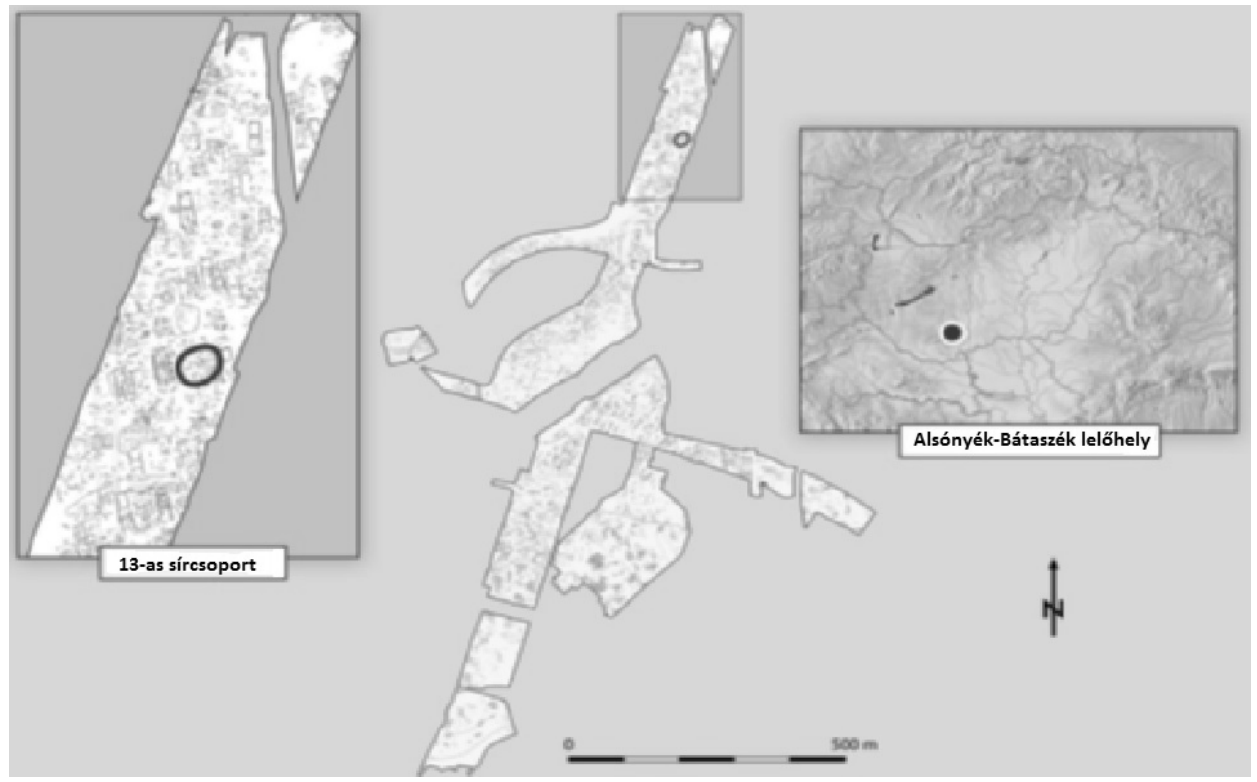

1. ábra: Áttekintő térkép az Alsónyék-Bátaszék késő neolit - kora rézkori lelőhelykomplexumról. A 13-as sírcsoport piros körrel jelölve.

Fig. 1: Overview map of the Neolithic site of Alsónyék-Bátaszék in Southern Hungary. The grave group 13 used in this study is highlighted with a red circle. 
A 13. sírcsoporthoz tartozó csontvázak morfológiai vizsgálata során Köhler és munkatársai feljegyeztek egy igen erőteljes Pott-gibbus-t mutató esetet (4027-es sírszám; Köhler 2012, Köhler és mtsai 2012). Ez a 4027-es sírszámú csontvázmaradvány a krónikus spondylitis tuberculosa egyértelmü, teljesen tipikus formáját mutatja, minden szempontból megfelel a tuberkulózis makromorfológiai-paleopatológiai diagnosztikus követelményeinek (pl. Pálfi és mtsai 1999, Ortner 2003).

A molekuláris vizsgálatokba 38 egyén csontvázát vontuk be a szóban forgó sírcsoportból - közöttük a fentebb említett elöre haladott Pott-gibbus-os esetet is. Az SZTE TTIK Embertani Tanszékén végzett előzetes morfológiai vizsgálatunk alkalmával a csontvázakon egyaránt tanulmányoztuk a tipikus és korai/atípusos tbc-tüneteket. A széria jó megtartási állapota, a fontos régészeti időszak és a tbc különböző morfológiai tüneteinek felismerése együttesen arra ösztönöztek bennünket, hogy minden egyénre kiterjedő, tbc-re fókuszáló archaikus DNS vizsgálatokat végezzünk az Alsónyék-Kanizsa dűlő teljes 13-as sírcsoportja esetében.

A paleomikrobiológiai analízis

A kiválasztott minta-sorozat (13-as sírcsoport) esetében a MTBC baktériumok diagnosztizálására irányuló molekuláris biológiai vizsgálatainkat a sírcsoport valamennyi, összesen 38 egyedén elvégeztük. Ahol arra lehetőségünk adódott, hosszú csont mintát és fogakat egyaránt bevontunk a vizsgálatokba.

A mintavétel egy erre kialakított, speciális archeogenetikai pre-PCR helyiségben történt, a DNS-vizsgálatoknak megfelelő szigorú körülmények biztosítása mellett: védőruházat használata, az eszközök UV fénnyel történő besugárzása és a felületek fertőtlenítése, a PCR során filteres pipetta hegyek alkalmazása. A mintavételekre Budapesten, az MTA BTK RI Archeogenetikai Laboratórium mintavételi helyiségében került sor, hogy megakadályozzuk a minták kontaminálódását. A vizsgálatok előkészitése is Budapesten történt. A paleomikrobiológiai vizsgálatokra a „EURAC Institute for Mummies and the Iceman” kutatólaboratóriumában került sor (Bolzano, Olaszország).

A preparáló helyiségben a minták külső felszínét mechanikailag eltávolítottuk Dremel fúrókészülék segítségével, majd az egyének mintáit Retsch örlőmalomban őröltük porrá. A szilika-alapú DNS extrakcióhoz 250 mg csontport használtunk. Az extrakciós elegy 5 $\mathrm{ml}$ EDTA-t és $20 \mu \mathrm{l} 20 \mathrm{mg} / \mathrm{ml}$ Proteinase K-t tartalmazott, keverést követően $40^{\circ} \mathrm{C}$-on inkubáltuk egy éjszakán át. A minták felülúszójához 2,5 ml kötő puffert és $100 \mu 1$ szilika szuszpenziót adtunk a DNS megkötése érdekében, ezt követően 3 órán keresztül inkubáltuk. A DNS kivonást - kisebb módosításokkal - a Nadin Rohland-féle protokoll alapján végeztük (Rohland és mtsai 2009).

A Mycobacterium tuberculosis komplex tagjai nagy többségének genomja ún. repetitív inzerciós elemeket tartalmaz, amelyek közül legismertebb az IS6110 inzerciós szekvencia (Taylor és mtsai 1996). A tbc baktérium DNS jelenlétének megállapítására több mint két évtizede PCR-alapú eljárást alkalmaznak, amelynek során a MTBC fentebb említett multikópiás IS6110 régióját célozzák meg (Eisenach és mtsai 1990).

Vizsgálataink során első lépésben hagyományos PCR eljárással IS6110F és IS6110R primer pár segítségével létrehoztuk a diagnosztikus értékủ 123 bázispáros szakaszt. A vizsgálat érzékenységét nested PCR stratégiával növeltük. Diagnózisunk pontosítására, ill. a M. tuberculosis komplex baktériumok altípusba sorolása érdekében a kiválasztott mintákon spoligotyping vizsgálatokat végeztünk a Kamerbeek és munkatársai által leírt metódus módosított változatát követve (Kamerbeek és mtsai 1997). 


\section{Vizsgálati eredmények és értékelésük}

Alsónyék-Bátaszék neolit temető 13-as sírcsoportjának mind a 38 humán csontvázmaradványát makroszkópos morfológiai és paleomikrobiológiai vizsgálatokba vontuk be. A vizsgálat elsődleges aktualitását adó 4027-es sírszámú Pott-gibbusos eset (2. ábra) mellett számos más egyén (n=17) mutatott atípusos tbc-elváltozásra (3. ábra) utaló csonttani markereket. Fontos megjegyeznünk, hogy a vizsgált maradványok között szerepeltek „morfológiailag negatív”, azaz olyan vázmaradványok is, amelyek egyáltalán nem mutattak a betegségre jellemző csonttani tüneteket $(\mathrm{n}=21)$. A vizsgált 38 egyénböl 5nél (13\%) kaptunk pozitív molekuláris eredményt baktérium DNS vizsgálata során tesztelt IS6110 repetitív elemre (1. táblázat). Érdekes és fontos adat, hogy az öt MTBC aDNS pozitív esetből egynél (ID 422) nem volt látható nyoma patológiás elváltozásnak.

Összesen hat lelet esetében kaptunk pozitív eredményt spoligotyping vizsgálat során (1. táblázat). A spoligotyping vizsgálatunk során azonban a mintázatok nagyon szórványos lefedettséget mutattak a DNS nagymértékủ degradációja miatt, így ezeket az eredményeket nem lehetett felhasználni további törzsi tipizálásához. Spoligotyping elemzésünket így kiegészítő vizsgálatként kezeltük, annak bizonyítására, hogy a MTBC aDNS valóban jelen volt az IS6110 pozitív mintákban. Ezért az olyan esetek, melyek csak spoligotyping vizsgálat során mutattak pozitív eredményt (ID 801, 813, 815), nem szerepelnek a molekulárisan tbc pozitív esetek között.

A 4027-es sírból származó 30-40 év közötti férfi különös jelentőséggel bír: a gerincen megfigyelhető jellegzetes krónikus spondylitis tuberculosa (Pott-féle púp) mellett a koponyán endocranialis elváltozások és cribra orbitalia, míg a bordákon és a hosszúcsontokon periostitis jeleit észleltük. Ebben az esetben mind a hosszúcsontokból, mind a fogakból vett minták esetén pozitív eredményt kaptunk az IS6110 repetitív elem tekintetében, ezzel egyértelmüen alátámasztva a Mycobacterium tuberculosis aDNS jelenlétét az egyén maradványaiban.

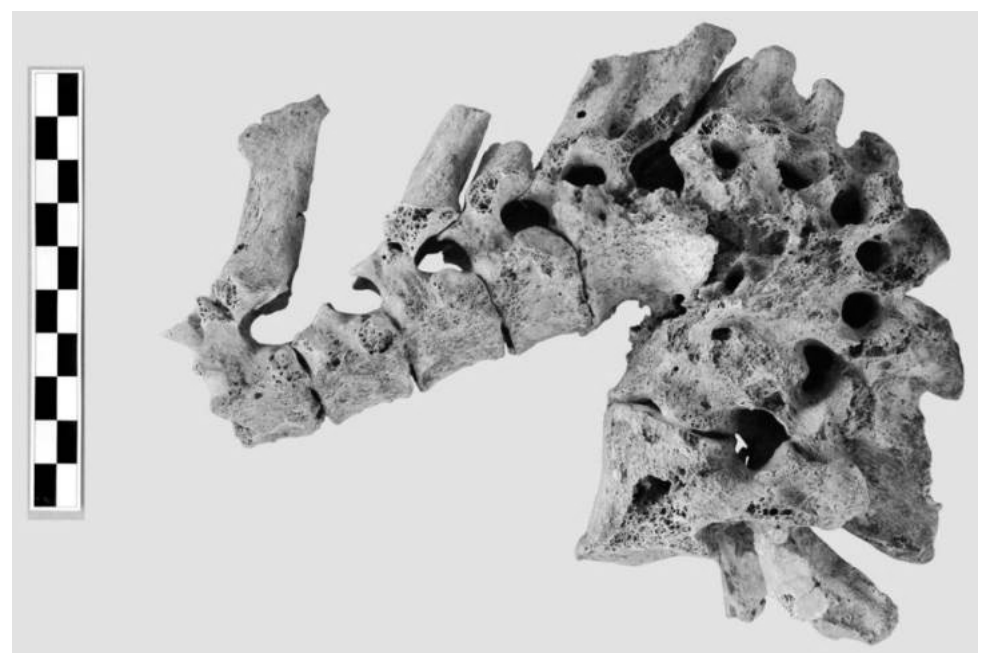

2. ábra: Súlyos, krónikus spondylitis tuberculosa (Pott-gibbus) eset az Alsónyék-Bátaszék lengyeli kultúra 4027-es sírjából.

Fig. 2. Severe case of chronic spondylitis tuberculosa (Pott’s disease) from Alsónyék-Bátaszék, grave no. 4027. 
1. táblázat. Az Alsónyék-Kanizsa dűlő lelőhely 13. sírcsoport 38 humán maradványa csontmintáinak morfológiai és molekuláris biológiai jellemzői.

Table 1. Morphological and molecular features of the bone samples from 38 individuals of the grave group 13 .

\begin{tabular}{|c|c|c|c|c|c|c|}
\hline $\begin{array}{l}\text { Esetszám } \\
\text { Case ID }\end{array}$ & $\begin{array}{l}\text { Elhalálozási kor } \\
\text { (év) - Age (ys) }\end{array}$ & $\begin{array}{l}\text { Nem } \\
\text { Sex }\end{array}$ & $\begin{array}{l}\text { Morfológiai lézió } \\
\text { Morphological lesion }\end{array}$ & $\begin{array}{l}\text { Minta típusa } \\
\text { Sample type }\end{array}$ & IS6110 & Spol. \\
\hline 256 & $6-7$ & - & $\begin{array}{l}\text { endocranialis elváltozás }{ }^{\# 1} \text {, borda } \\
\text { és hosszú csont periostitis }{ }^{ \pm 2}\end{array}$ & $\begin{array}{l}\text { fog }- \text { tooth } \\
\text { tibia }\end{array}$ & $\begin{array}{l}- \\
+\end{array}$ & $\begin{array}{l}\text { Sp38 } \\
\text { n.d. }\end{array}$ \\
\hline 396 & $1-2$ & - & - & $\begin{array}{l}\text { fog }- \text { tooth } \\
\text { radius }\end{array}$ & $\begin{array}{l}- \\
-\end{array}$ & $\begin{array}{l}\text { n.d. } \\
\text { n.d. }\end{array}$ \\
\hline 398 & n.d. & n.d. & $\begin{array}{l}\text { periostitis mindkét tibián és } \\
\text { fibulán }\end{array}$ & $\begin{array}{l}\text { fog - tooth } \\
\text { femur }\end{array}$ & $\begin{array}{l}- \\
-\end{array}$ & - \\
\hline 422 & $11-12$ & - & - & $\begin{array}{l}\text { fog }- \text { tooth } \\
\text { femur }\end{array}$ & $\begin{array}{l}- \\
+\end{array}$ & $\begin{array}{l}\text { Sp7 } \\
\text { Sp43 }\end{array}$ \\
\hline 423 & $23-59$ & $\begin{array}{l}\text { férfi } \\
\text { male }\end{array}$ & - & $\begin{array}{l}\text { kop. frag. } \\
\text { kop. frag. }\end{array}$ & $\begin{array}{l}- \\
-\end{array}$ & $\begin{array}{l}\text { n.d. } \\
\text { n.d. }\end{array}$ \\
\hline 782 & $20-23$ & - & - & $\begin{array}{l}\text { fog - tooth } \\
\text { femur }\end{array}$ & $\begin{array}{l}- \\
-\end{array}$ & $\begin{array}{l}\text { n.d. } \\
\text { n.d. }\end{array}$ \\
\hline 783 & $40-59$ & $\begin{array}{l}\text { férfi } \\
\text { male }\end{array}$ & $\begin{array}{c}\text { enyhe hosszú csont } \\
\text { periostitis }^{\sharp 4}\end{array}$ & $\begin{array}{l}\text { fog - tooth } \\
\text { femur }\end{array}$ & $\begin{array}{l}- \\
-\end{array}$ & $\begin{array}{l}\text { n.d. } \\
\text { n.d. }\end{array}$ \\
\hline 784 & $6-8$ & - & endocranialis elváltozás ${ }^{\# 1}$ & $\begin{array}{l}\text { fog - tooth } \\
\text { femur }\end{array}$ & $\begin{array}{l}- \\
-\end{array}$ & $\begin{array}{l}\text { n.d. } \\
\text { n.d. }\end{array}$ \\
\hline 785 & $35-45$ & $\begin{array}{c}\text { nő } \\
\text { female }\end{array}$ & - & $\begin{array}{l}\text { fog - tooth } \\
\text { femur }\end{array}$ & $\begin{array}{l}- \\
-\end{array}$ & $\begin{array}{l}\text { n.d. } \\
\text { n.d. }\end{array}$ \\
\hline 791 & $40-50$ & $\begin{array}{l}\text { férfi } \\
\text { male }\end{array}$ & $\begin{array}{l}\text { periostitis a hosszú csonton, } \\
\text { csigolyatörés }{ }^{\# 5}\end{array}$ & $\begin{array}{l}\text { fog - tooth } \\
\text { femur }\end{array}$ & $\begin{array}{l}- \\
+\end{array}$ & $\begin{array}{l}\text { n.d. } \\
\text { Sp4 }\end{array}$ \\
\hline 792 & $50-59$ & $\begin{array}{l}\text { férfi } \\
\text { male }\end{array}$ & - & $\begin{array}{l}\text { fog }- \text { tooth } \\
\text { femur }\end{array}$ & $\begin{array}{l}- \\
-\end{array}$ & $\begin{array}{l}\text { n.d. } \\
\text { n.d. }\end{array}$ \\
\hline 793 & $8-9$ & - & - & $\begin{array}{l}\text { fog - tooth } \\
\text { femur }\end{array}$ & $\begin{array}{l}- \\
-\end{array}$ & $\begin{array}{l}\text { n.d. } \\
\text { n.d. }\end{array}$ \\
\hline 794 & $16-18$ & - & - & $\begin{array}{l}\text { fog - tooth } \\
\text { femur }\end{array}$ & $\begin{array}{l}- \\
-\end{array}$ & $\begin{array}{l}\text { n.d. } \\
\text { n.d. }\end{array}$ \\
\hline 796 & $23-26$ & $\begin{array}{c}\text { nö } \\
\text { female }\end{array}$ & 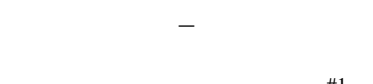 & $\begin{array}{l}\text { fog - tooth } \\
\text { femur }\end{array}$ & $\begin{array}{l}- \\
-\end{array}$ & $\begin{array}{l}\text { n.d. } \\
\text { n.d. }\end{array}$ \\
\hline 797 & $10-12$ & - & endocranialis elváltozás ${ }^{\# 1}$ & $\begin{array}{l}\text { fog }- \text { tooth } \\
\text { femur }\end{array}$ & $\begin{array}{l}- \\
-\end{array}$ & $\begin{array}{l}\text { n.d. } \\
\text { n.d. }\end{array}$ \\
\hline 798 & $50-60$ & férfi & - & $\begin{array}{l}\text { fog }- \text { tooth } \\
\text { femur }\end{array}$ & $\begin{array}{l}- \\
-\end{array}$ & $\begin{array}{l}\text { n.d. } \\
\text { n.d. }\end{array}$ \\
\hline 799 & $35-45$ & nö & - & $\begin{array}{l}\text { fog - tooth } \\
\text { femur }\end{array}$ & $\begin{array}{l}- \\
-\end{array}$ & $\begin{array}{l}\text { n.d. } \\
\text { n.d. }\end{array}$ \\
\hline 800 & $40-45$ & nö & - & $\begin{array}{l}\text { fog - tooth } \\
\text { femur }\end{array}$ & $\begin{array}{l}- \\
-\end{array}$ & $\begin{array}{l}\text { n.d. } \\
\text { n.d. }\end{array}$ \\
\hline 801 & $3-5$ & - & $\begin{array}{l}\text { bilateralis cribra orbitalia és } \\
\text { borda periostitis }^{\# 6}\end{array}$ & $\begin{array}{l}\text { fog - tooth } \\
\text { femur }\end{array}$ & $\begin{array}{l}- \\
-\end{array}$ & $\begin{array}{l}\text { n.d. } \\
\text { Sp30 }\end{array}$ \\
\hline 802 & $15-18$ & - & - & $\begin{array}{l}\text { fog - tooth } \\
\text { femur }\end{array}$ & $\begin{array}{l}- \\
-\end{array}$ & $\begin{array}{l}\text { n.d. } \\
\text { n.d. }\end{array}$ \\
\hline
\end{tabular}

Spol.: spoligotyping, n.d.: nem vizsgálható - not determined, kop. frag.: fragmentum - fragment, +: pozitív PCR eredmény - positive PCR result, -: negatív PCR eredmény -negative PCR result, ${ }^{\# 1}$ : endocranial lesions, ${ }^{\# 2}$ : rib periostitis, long bone periostitis, ${ }^{\# 3}$ : periostitis on both the tibia and fibula, ${ }^{\# 4}$ : slight long bone periostitis, ${ }^{\# 5}$ : periostitis on long bone, vertebral fracture, ${ }^{\# 6}$ : bilateral cribra orbitalia and rib periostitis 
1. táblázat folyt. - Table 1 cont'd.

\begin{tabular}{|c|c|c|c|c|c|c|}
\hline $\begin{array}{l}\text { Esetszám } \\
\text { Case ID }\end{array}$ & $\begin{array}{l}\text { Elhalálozási kor } \\
\text { (év) - Age (ys) }\end{array}$ & $\begin{array}{l}\text { Nem } \\
\text { Sex }\end{array}$ & $\begin{array}{l}\text { Morfológiai lézió } \\
\text { Morphological lesion }\end{array}$ & $\begin{array}{l}\text { Minta típusa } \\
\text { Sample type }\end{array}$ & IS6110 & Spol. \\
\hline 803 & $25-35$ & $\begin{array}{l}\text { férfi } \\
\text { male }\end{array}$ & - & $\begin{array}{l}\text { fog - tooth } \\
\text { femur }\end{array}$ & $\begin{array}{l}- \\
-\end{array}$ & $\begin{array}{l}\text { n.d. } \\
\text { n.d. }\end{array}$ \\
\hline 804 & $7-8$ & - & $\begin{array}{l}\text { endocranialis elváltozás }{ }^{\# 1} \text {, } \\
\text { csigolya hipervascularisatio }^{\# 7}\end{array}$ & $\begin{array}{l}\text { fog }- \text { tooth } \\
\text { femur }\end{array}$ & - & $\begin{array}{l}\text { n.d. } \\
\text { n.d. }\end{array}$ \\
\hline 805 & $30-40$ & $\begin{array}{c}\text { nő } \\
\text { female }\end{array}$ & $\begin{array}{l}\text { endocranialis elváltozás" } \\
\text { periostitis a tibiákon }{ }^{\# 8}\end{array}$ & $\begin{array}{l}\text { fog - tooth } \\
\text { femur }\end{array}$ & $\begin{array}{l}- \\
-\end{array}$ & $\begin{array}{l}\text { n.d. } \\
\text { n.d. }\end{array}$ \\
\hline 808 & $35-45$ & $\begin{array}{l}\text { férfi } \\
\text { male }\end{array}$ & - & $\begin{array}{l}\text { fog }- \text { tooth } \\
\text { femur }\end{array}$ & $\begin{array}{l}- \\
-\end{array}$ & $\begin{array}{l}\text { n.d. } \\
\text { n.d. }\end{array}$ \\
\hline 809 & $50-55$ & $\begin{array}{l}\text { férfi } \\
\text { male }\end{array}$ & - & $\begin{array}{l}\text { fog- tooth } \\
\text { femur }\end{array}$ & $\begin{array}{l}- \\
-\end{array}$ & $\begin{array}{l}\text { n.d. } \\
\text { n.d. }\end{array}$ \\
\hline 810 & $35-45$ & $\begin{array}{l}\text { nő } \\
\text { female }\end{array}$ & - & $\begin{array}{l}\text { fog }- \text { tooth } \\
\text { femur }\end{array}$ & $\begin{array}{l}- \\
-\end{array}$ & $\begin{array}{l}\text { n.d. } \\
\text { n.d. }\end{array}$ \\
\hline 811 & $23-26$ & - & $\begin{array}{l}\text { endocranialis elváltozás }{ }^{\# 1} \text {, } \\
\text { cribra cranii, cribra orbitalia, } \\
\text { hosszú csont periostitis }^{\# 9}\end{array}$ & $\begin{array}{l}\text { fog - tooth } \\
\text { femur }\end{array}$ & $\begin{array}{l}- \\
+\end{array}$ & $\begin{array}{l}\text { n.d. } \\
-\end{array}$ \\
\hline 812 & $20-25$ & $\begin{array}{c}\text { nö } \\
\text { female }\end{array}$ & $\begin{array}{l}\text { csigolya hipervascu- } \\
\text { larisatio }{ }^{\# 7} \text {, súlyos hosszú } \\
\text { csont periostitis }^{\# 10}\end{array}$ & $\begin{array}{l}\text { fog - tooth } \\
\text { tibia }\end{array}$ & - & $\begin{array}{l}- \\
-\end{array}$ \\
\hline 813 & $25-35$ & $\begin{array}{l}\text { férfi } \\
\text { male }\end{array}$ & $\begin{array}{l}\text { endocranialis elváltozás }{ }^{\# 1} \text {, cribra } \\
\text { orbitalia, periostits tibián }{ }^{\# 11}\end{array}$ & $\begin{array}{l}\text { fog - tooth } \\
\text { femur }\end{array}$ & $\begin{array}{l}- \\
-\end{array}$ & $\begin{array}{c}- \\
\text { Sp6,10, } \\
11,38\end{array}$ \\
\hline 815 & n.d. & n.d. & - & fog - tooth & - & $\begin{array}{l}\text { Sp14, } \\
19,22, \\
23\end{array}$ \\
\hline & & & & femur & - & - \\
\hline 817 & 25-35 & $\begin{array}{l}\text { nö } \\
\text { female }\end{array}$ & - & $\begin{array}{l}\text { fog - tooth } \\
\text { femur }\end{array}$ & $\begin{array}{l}- \\
-\end{array}$ & $\begin{array}{l}\text { n.d. } \\
\text { n.d. }\end{array}$ \\
\hline 818 & $40-59$ & $\begin{array}{l}\text { nő } \\
\text { female }\end{array}$ & $\begin{array}{l}\text { endocranialis elváltozás }{ }^{\# 1} \text {, } \\
\text { hosszú csont periostitis }{ }^{\# 9}\end{array}$ & $\begin{array}{l}\text { femur } \\
\text { femur }\end{array}$ & $\begin{array}{l}- \\
-\end{array}$ & $\begin{array}{l}\text { n.d. } \\
\text { n.d. }\end{array}$ \\
\hline 819 & $23-30$ & $\begin{array}{l}\text { férfi } \\
\text { male }\end{array}$ & $\begin{array}{l}\text { periostitis a fibulán és a } \\
\text { femuron }^{\# 12} \text {, csigolya } \\
\text { hipervascularisatio }^{\# 7}\end{array}$ & $\begin{array}{l}\text { femur } \\
\text { femur }\end{array}$ & $\begin{array}{l}- \\
-\end{array}$ & $\begin{array}{l}- \\
-\end{array}$ \\
\hline 853 & $40-50$ & $\begin{array}{c}\text { nö } \\
\text { female }\end{array}$ & - & $\begin{array}{l}\text { fog - tooth } \\
\text { tibia }\end{array}$ & $\begin{array}{l}- \\
-\end{array}$ & $\begin{array}{l}\text { n.d. } \\
\text { n.d. }\end{array}$ \\
\hline 4011 & $25-28$ & $\begin{array}{l}\text { férfi } \\
\text { male }\end{array}$ & $\begin{array}{l}\text { cribra orbitalia, periostitis a } \\
\text { femuron, tibián és fibulán }\end{array}$ & $\begin{array}{l}\text { fog - tooth } \\
\text { femur }\end{array}$ & $\begin{array}{l}- \\
-\end{array}$ & $\begin{array}{l}\text { n.d. } \\
\text { n.d. }\end{array}$ \\
\hline 4012 & 25-30 & $\begin{array}{l}\text { nö } \\
\text { female }\end{array}$ & - & $\begin{array}{l}\text { fog - tooth } \\
\text { tibia }\end{array}$ & $\begin{array}{l}- \\
-\end{array}$ & $\begin{array}{l}\text { n.d. } \\
\text { n.d. }\end{array}$ \\
\hline 4027 & $30-40$ & $\begin{array}{l}\text { férfi } \\
\text { male }\end{array}$ & $\begin{array}{l}\text { endocranialis elv. }^{\# 1} \text {, cribra orbit- } \\
\text { alia, borda periostitis, hosszú } \\
\text { csont periostitis }^{\# 2} \text {, spondylitis } \\
\text { tuberculosa (Pott gibbus) }\end{array}$ & $\begin{array}{l}\text { fog - tooth } \\
\text { femur }\end{array}$ & $\begin{array}{l}+ \\
+\end{array}$ & $\begin{array}{l}- \\
-\end{array}$ \\
\hline 4028 & $20-25$ & $\begin{array}{l}\text { férfi } \\
\text { male }\end{array}$ & $\begin{array}{l}\text { bilateralis cribra orbitalia, } \\
\text { endocranialis elváltozás }{ }^{\# 1} \text {, } \\
\text { hosszú csont periostitis }^{\# 9}\end{array}$ & $\begin{array}{l}\text { fog - tooth } \\
\text { femur }\end{array}$ & $\begin{array}{l}- \\
-\end{array}$ & $\begin{array}{l}\text { n.d. } \\
\text { n.d. }\end{array}$ \\
\hline
\end{tabular}




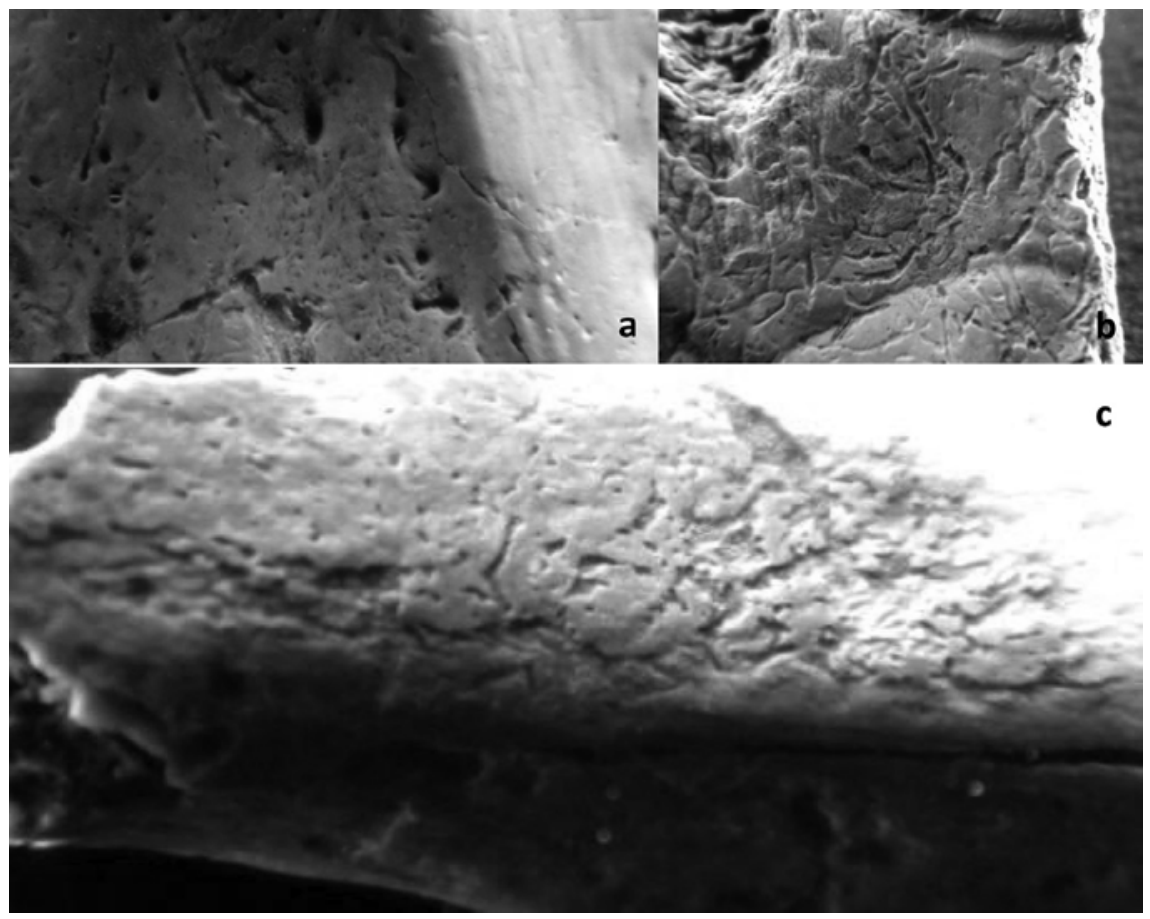

3. ábra: 6-7 éves gyermek csontmaradványain (ID 256) megfigyelhető endocranialis lézió (a-b) és borda periostitis (c) nyomok.

Fig. 3: Skeletal remains of a 6-7 year-old young child (case ID 256) with endocranial lesions (a-b) and rib periostitis (c).

\section{Következtetések}

Kutatásainkban molekuláris biológiai és paleopatológiai vizsgálatokat végeztünk, annak érdekében, hogy pontosítsuk a tbc fertözöttség szintjét és formáit a késő neolit-kora rézkori Alsónyék-Kanizsa dűlő oszteoarcheológiai széria 38 emberi maradványára vonatkozóan. Eredményeink jelzik, összhangban a már publikált morfológiai adatokkal (Köhler 2012, Köhler és mtsai 2013), hogy a Mycobacterium tuberculosis fertőzés jelen volt a sírcsoportba eltemetett korabeli népességben, a tanulmányozott alsónyéki prehisztorikus populációban.

A tanulmány alátámasztja a Masson és munkatársai (Masson és mtsai 2013, 2015) által közölt magyarországi neolit tuberkulózis-előfordulást, és számos új esettel kiegészítve konfirmálja a MTBC jelenlétét és humánpatogén mivoltát a mintegy 7000 évvel ezelötti Közép-Európában. Az Alsónyék-Kanizsa dűlő 13-as sírcsoport csontmaradványainak fontosságát a település földrajzi elhelyezkedése, különleges kronológiai időszaka, a klasszikus tbc elváltozások jelenléte és az elért MTBC aDNS eredmények egyaránt felértékelik. A lelöhely további érdekessége annak rendkívül nagy kiterjedése, a mintegy 120 házzal és a temető 2359 sírjával. A tuberkulózis jelenléte és bizonyítottan humánpatogén jellege ebben a populációban kivételes fontossággal bír, tekintve a neolit kori Európa kulturális és demográfiai viszonyait. Ennek a komplex kontextusnak a tanulmányozása segíthet talán megérteni, hogyan sürüsödhetett ekkora 
populáció egyetlen településben, és aránylag rövid idővel később miért tünt el olyan gyorsan erről a területről a népesség a Lengyel kultúra után (Kr.e. 5. évezred közepén). További vizsgálatok szükségesek annak kiderítése érdekében, hogy megállapítsuk, a M. tuberculosis komplex mely tagja fertőzte meg az alsónyéki populációt. A tuberkulózis valóban szerepet játszott-e a későbbi radikális népesség-csökkenésben, és hogy a jelenleginél pontosabb ismereteink lehessenek az Alföld és Dél-Dunántúl neolitikumban élt populációinak tbc-fertőzöttségi rátájáról.

\section{A tanulmányt Dr. K. Zoffmann Zsuzsanna emlékének ajánljuk.}

Köszönetnyilvánítás: A kutatás a K78555, K81230 és NN 78696 számú OTKA pályázatok, a TÁMOP-4.2.4.A/ 2-11-1-2012-0001 „National Excellence Program” és a „Südtiroler Sparkasse and the South Tyrolean grant legge 14” támogatásaival valósult meg, amelyekért szerzők ezúttal mondanak köszönetet.

\section{Irodalom}

Baker, O., Lee, O.Y., Wu, H.H., Besra, G.S., Minnikin, D.E., Llewellyn, G., Williams, C.M., Maixner, F., O'Sullivan, N., Zink, A., Chamel, B., Khawam, R., Coqueugniot, E., Helmer, D., Le Mort, F., Perrin, P., Gourichon, L., Dutailly, B., Pálfi, G., Coqueugniot, H., Dutour, O. (2015): Human tuberculosis predates domestication in ancient Syria. Tuberculosis, 95(Suppl. 1): S4-S12. DOI: $10.1016 / \mathrm{j}$. tube.2015.02.001

Bos, KI., Harkins, KM., Herbig, A., Coscolla, M., Weber, N., Comas, I., Forrest, SA., Bryant, JM., Harris, SR., Schuenemann, VJ., Campbell, TJ., Majander, K., Wilbur, AK., Guichon, RA., Steadman, DLW., Cook, DC., Niemann, S., Behr, MA., Zumarraga, M., Bastida, R., Huson, D., Nieselt, K., Young, D., Parkhill, J., Buikstra, JE., Gagneux, S., Stone, AC. Krause, J. (2014): Pre-Columbian mycobacterial genomes reveal seals as a source of New World human tuberculosis. Nature, 514: 494-497. DOI: 10.1038/nature13591

Boritsch, EC., Supply, P., Honoré, N., Seeman, T., Stinear, TP., Brosch, R. (2014): A glimpse into the past and predictions for the future: the molecular evolution of the tuberculosis agent. Molecular Microbiology, 93 (5): 835-852. DOI: 10.1111/mmi.12720

Brisse, S., Supply, P., Brosch, R., Vincent, V., Gutierrez, MC. (2009): „A re-Evaluation of M. prototuberculosis": Continuing the debate. PLoS Pathogens, 2(9): e95. DOI: 10.1371/journal.ppat.0020095

Brosch, R., Gordon, S.V., Marmiesse, M., Brodin, P., Buchrieser, C., Eiglmeier, K., Garnier, T., Gutierrez, C., Hewinson, G., Kremer, K., Parsons, L.M., Pym, A.S., Samper, S., van Soolingen, D., Cole, S.T. (2002): A new evolutionary scenario for the Mycobacterium tuberculosis complex. Proceedings of National Academy of Sciences of the USA, 99: 3684-3689. DOI: 10.1073/pnas.052548299

Cockburn, A. (1963): The evolution and eradication of infectious disease. J. Hopkins Press, Baltimore.

Cole, S.T., Brosch, R., Parkhill, J., Garnier, T., Churcher, C., Harris, D., Gordon, S.V., Eiglmeier, K., Gas, S., Barry, C., Tekaia, F., Badcock, K., Basham, D., Brown, D., Chillingworth, T., Connor, R., Davies, R., Devlin, K., Feltwell, T., Gentles, S., Hamlin, N., Holroyd, S., Hornsby, T., Jagels, K., Krogh, A., McLean, J., Moule, S., Murphy, L., Oliver, K., Osborne, J., Quail, M.A., Rajandream, M.A., Rogers, J., Rutter, S., Skelton, J., Squares, R., Squares, S., Sulston, J., Taylor, K., Whitehead, S., Barrell. B. (1998): Deciphering the biology of Mycobacterium tuberculosis from the complete genome sequence. Nature, 393: 537-544. DOI: 10.1038/31159 
Comas, I., Coscolla, M., Luo, T., Borrell, S., Holt, K.E., Kato-Maeda, M., Parkhill. J., Malla, B., Berg, S., Thwaites, G., Yeboah-Manu, D., Bothamley, G., Mei, J., Wei, L., Bentley, L., Harris, S.R., Niemann, S., Diel, R., Aseffa, A., Gao, Q., Young, D., Gagneux, S. (2013): Out-of-Africa migration and Neolithic co-expansion of Mycobacterium tuberculosis with modern humans. Nature Genetics, 45 (10): 1176-1182. DOI: 10.1038/ng.2744

Donoghue, H.D. (2009): Human tuberculosis - an ancient disease, as elucidated by ancient microbial biomolecules. Microbes and Infection, 11: 1156-1162. DOI: 10.1016/j.micinf.2009.08.008

Donoghue, H.D., Spigelman, M., O’Grady, J., Szikossy, I., Pap, I., Lee, OYC., Wu, H.H.T., Besra, G.S., Minnikin, D.E. (2015): Ancient DNA analysis - An established technique in charting the evolution of tuberculosis and leprosy. Tuberculosis, 95(S1): S140-S144. DOI: 10.1016/j.tube.2015.02.020

Eisenach, K.D., Cave, M.D., Bates, J.H., Crawford, J.T. (1990): Polymerase chain reaction amplification of a repetitive DNA sequence specific for Mycobacterium tuberculosis. Journal of Infectious Diseases, 161: 977-981. DOI: 10.1093/infdis/161.5.977

Filliol, I., Motiwala, A.S., Cavatore, M., Qi, W., Hazbo, MH., Bobadilla del Valle, M., Fyfe, J., Garcia-Garcia, L., Rastogi, N., Sola, C., Zozia, T., Guerrero, MI., Leon, CI., Crabtree, J., Angiuoli, S., Eisenach, K.D., Durmaz, R., Joloba, M.L., Rendon, A., Sifuentes-Osornio, J., Ponce de Leon, A., Cave, D.M., Fleischmann, R., Whittam, T.S., Alland, D. (2006): Global phylogeny of Mycobacterium tuberculosis based on single nucleotide polymorphism (SNP) analysis: insights into tuberculosis evolution, phylogenetic accuracy of other DNA fingerprinting systems, and recommen-dations for a minimal standard SNP set. Journal of Bacteriology, 188: 759-772. DOI: 10.1128/JB.188.2.759-772.2006

Gutierrez, M.C., Brisse, S., Brosch, R., Fabre, M., Omais, B., Marmiesse, M., Supply, P., Vincent, V. (2005): Ancient origin and gene mosaicism of the progenitor of Mycobacterium tuberculosis. PLoS Pathogens, 1(1): e5. DOI: 10.1371 /journal.ppat.0010005

Hershberg, R., Lipatov, M., Small, P.M., Sheffer, H., Niemann, S., Homolka, S., Roach, J.C., Kremer, K., Petrov, D.A., Feldman, M.W., Gagneux, S. (2008): High functional diversity in Mycobacterium tuberculosis driven by genetic drift and human demography. PLoS Biology, 6: e311. DOI: 10.1371/journal.pbio.0060311

Hershkovitz, I., Donoghue, H.D., Minnikin, D.E., Besra, G.S., Lee, O.Y-C., Gernaey, A.M., Galili, E., Eshed, V., Greenblatt, C.L, Lemma, E., Bar-Gal, G.K., Spigelman M., (2008): Detection and molecular characterization of 9000-year-old Mycobacterium tuberculosis from a Neolithic settlement in the Eastern Mediterranean. PLoSOne, 3(10): e3426. DOI: 10.1371/journal.pone.0003426

Kamerbeek, J., Schouls, L., Kolk A., van Agterveld, M., van Soolingen, D., Kuijper, S., Bunschoten, A., Molhuizen, H., Shaw, R., Goyal, M., van Embden, J. (1997): Simultaneous detection and strain differentiation of Mycobacterium tuberculosis for diagnosis and epidemiology. Journal of Clinical Microbiology, 35: 907-914.

Köhler, K. (2012): A késö neolitikus lengyeli kultúra népességének biológiai rekonstrukciója. Doktori disszertáció. ELTE, Embertani Tanszék, Budapest.

Köhler, K., Pálfi, G., Molnár, E., Zalai-Gaál, I., Osztás, A., Bánffy, E., Kirinó, K., Kiss, K.K., Mende, B.G. (2012): A Late Neolithic case of Pott's disease from Hungary. International Journal of Osteoarchaeology, 24(6): 697-703. DOI: 10.1002/oa.225

Köhler, K., Mende, B.G., Pósa, A. (2013): The emergence of tuberculosis in Late Neolithic Transdanubia. Magyar Régészet. http://www.hungarianarchaeology.hu/wpcontent/uploads/2013/08/eng_Kohler_13ny1.pdf

Masson, M., Bereczki, Zs., Molnár, M., Donoghue, H.D., Minnikin, D.E., Lee, O.Y-C., Wu, H.H.T., Besra, GS., Bull, ID., Pálfi, G. (2015): 7000 year-old tuberculosis cases from Hungary. Tuberculosis, 95(S1): S13-17. DOI: 10.1016/j.tube.2015.02.007 
Masson, M., Molnár, E., Donoghue, H.D., Besra, G.S., Minnikin, D.E., Wu H.H.T., Lee O.Y-C., Bull, I.D., Pálfi, Gy. (2013): Osteological and biomolecular evidence of a 7000-year-old case of hypertrophic pulmonary osteopathy secondary to tuberculosis from Neolithic Hungary. PLoSOne, 8(10): e78252. DOI: 10.1371/journal.pone.0078252

Nicklisch, N., Maixner, F., Ganslmeier, R., Friederich, S., Dresely, V., Meller, H., Zink, A. (2012): Rib lesions in skeletons from early neolithic sites in Central Germany: on the trail of tuberculosis at the onset of agriculture. American Journal of Physical Anthropology, 149(3): 391-404. DOI: 10.1002/ajpa.22137

Ortner, D.J. (2003): Identifications of Pathological Conditions in Human Skeletal Remains. Academic Press, Elsevier Science, San Diego.

Pálfi, Gy., Dutour, O., Deák, J., Hutás, I. (1999, Eds): Tuberculosis: Past and Present. Golden Book Publisher, Tuberculosis Foundation, Budapest - Szeged.

Pálfi, Gy., Dutour, O., Perrin, P., Sola, C., Zink, A. (2015): Tuberculosis in Evolution. Tuberculosis, 95(S1): S1-3. DOI: 10.1016/j.tube.2015.04.007

Rohland, N., Siedel, H., Hofreiter, M. (2009): A rapid column-based ancient DNA extraction method for increased sample throughput. Molecular Ecology Resources, 10(4): 677-683. DOI: 10.1111/j.1755-0998.2009.02824.X

Smith, N.H., Hewinson, R.G., Kremer, K., Brosch, R., Gordon, S.V. (2009): Myths and misconceptions: the origin and evolution of Mycobacterium tuberculosis. Naturee Reviews Microbiology, 7: 537-543. DOI: $10.1038 /$ nrmicro2165

Taylor, G.M., Crossey, M., Saldanha, J., Waldron, T. (1996): Mycobacterium tuberculosis identified in mediaeval human skeletal remains using polymerase chain reaction. Journal of Archaeological Science, 23: 789-798. DOI: 10.1006/jasc.1996.0073

Wirth, T., Hildebrand, F., Allix-Béguec, C., Wölbeling, F., Kubica, T., Kremer, K., van Soolingen, D., Rüsch-Gerdes, S., Locht, C., Brisse, S., Meyer, A., Supply, P., Niemann, S. (2008): Origin, Spread and demography of the Mycobacterium tuberculosis complex. PLoS Pathogens, 4(9): e1000160. DOI: 10.1371/journal.ppat.1000160

World Health Organization (2015): Global Tuberculosis Report 2015. World Health Organization, Geneva.

Zalai-Gaál, I. (2008): An der Wende vom Neolithikum zur Kupferzeit in Transdanubien: Die „Häuptlingsgräber” der Lengyel-Kultur in Alsónyék-Kanizsa-dűlő. Das Altertum, 53: 241-280.

Zalai-Gaál, I., Osztás, A. (2009): Neue Aspekte zur Erforschungdes Neolithikums in Ungarn. Ein Fragenkatalog zu Siedlung und Gräberfeld der Lengyel-Kultur von Alsónyék, Südtransdanubien. In: Becker, V., Thomas, M., Wolf-Schuler, A. (Hrsg.) Zeiten - Kulturen Systeme. Gedenkschrift für Jan Lichardus. ZAKS Bd. 17, Langenweißbach. pp. 111-139.

Levelezési cím:

Mailing address:
Pósa Annamária

Magyar Tudományos Akadémia, Bölcsészettudományi Kutatóközpont, Régészeti Intézet, Archeogenetikai Laboratórium

Úri u. 49.

H-1014 Budapest

Hungary

Posa.Annamaria@btk.mta.hu 
